\title{
Molecular and cellular basis of bone resorption
}

\author{
Reinhard Gruber
}

Received: 21 August 2014 / Accepted: 27 August 2014 / Published online: 16 September 2014

(C) Springer-Verlag Wien 2014

Summary Osteoclast research has an exciting history and a challenging future. More than 3 decades ago, it became evident that bone-resorbing osteoclasts are of hematopoietic origin and are ultimately linked to the "basic multicellular unit," where they team up with the other cell types, including bone-forming osteoblasts. Since 2 decades, we have learned about the signaling pathways controlling genes relevant for osteoclastogenesis and bone resorption. It took another decade until the hypothesized "osteoclast differentiation factor" was discovered and was translated into an approved pharmacologic strategy. Here, the focus is on another molecular target, cathepsin $\mathrm{K}$, a cysteine protease being released by the osteoclast into the resorption compartment. Genetic deletion and pharmacological blocking of cathepsin $\mathrm{K}$ reduces bone resorption but with ongoing bone formation. This observation not only holds great promise to become a new pharmacologic strategy, but it also provides new insights into the coordinated work of cells in the "basic multicellular unit" and thus, bridges the history and future of osteoclast research. This article is a short primer on osteoclast biology for readers of the special issue on odanacatib, a cathepsin K inhibitor.

Keywords Osteoclast · Bone remodeling, signaling $\cdot$ Resorption $\cdot$ Sealing zone $\cdot$ Ruffled boarder

R. Gruber, $\mathrm{PhD}(\triangle)$

Laboratory of Oral Cell Biology, School of Dental Medicine,

University of Bern,

Freiburgstrasse 7,

3010 Bern, Switzerland

e-mail: reinhard.gruber@zmk.unibe.ch

\section{Molekulare und zelluläre Grundlagen der Knochenresorption}

Zusammenfassung Die Erforschung der Osteoklasten hat eine interessante Historie und eine herausfordernde Zukunft. Vor mehr als drei Jahrzehnten wurde deutlich, dass die Osteoklasten hämatopoetischen Ursprungs sind und sich gemeinsam mit den anderen Zelltypen, einschließlich der knochenbildenden Osteoblasten, in der „Basic Multicellular Unit“, befinden. Seit zwei Jahrzehnten verdichtet sich das Wissen über die Signalwege zur Kontrolle der Osteoklastogenese und der Knochenresorption. Es dauerte ein weiteres Jahrzehnt bis der hypothetische „Osteoklasten-Differenzierungsfaktor“ entdeckt wurde der, in Folge, die Grundlage für eine zugelassene pharmakologische Strategie bildete. Ein anderes molekulares Ziel ist Cathepsin K, einem Cystein-Protease die vom Osteoklasten währen der Resorption freigesetzt wird. Genetische Deletion und pharmakologische Blockierung von Cathepsin $\mathrm{K}$ reduzieren die Knochenresorption, ohne Unterbrechung der Knochenneubildung. Dieses Prinzip hat das Potential eine neue pharmakologische Strategie zu werden und bietet neue Einblicke in die koordinierte Arbeit der Zellen in der „Basic Multicellular Unit“. Dieses Prinzip verbindet auch die Historie und Zukunft der Erforschung der Osteoklasten. Dieser Artikel ist ein kurzer Abriss der Osteoklastenbiologie für die Leser der Sonderausgabe zum Thema Odanacatib, einem Cathepsin-K-Inhibitor.

Schlüsselwörter Cathepsin K · Osteoclast · Resorption · Signaling $\cdot$ Review $\cdot$ Remodeling

\section{Anatomy and biochemistry of the osteoclast}

The molecular and cellular basis of bone resorption should not be reviewed without referring to the "basic 

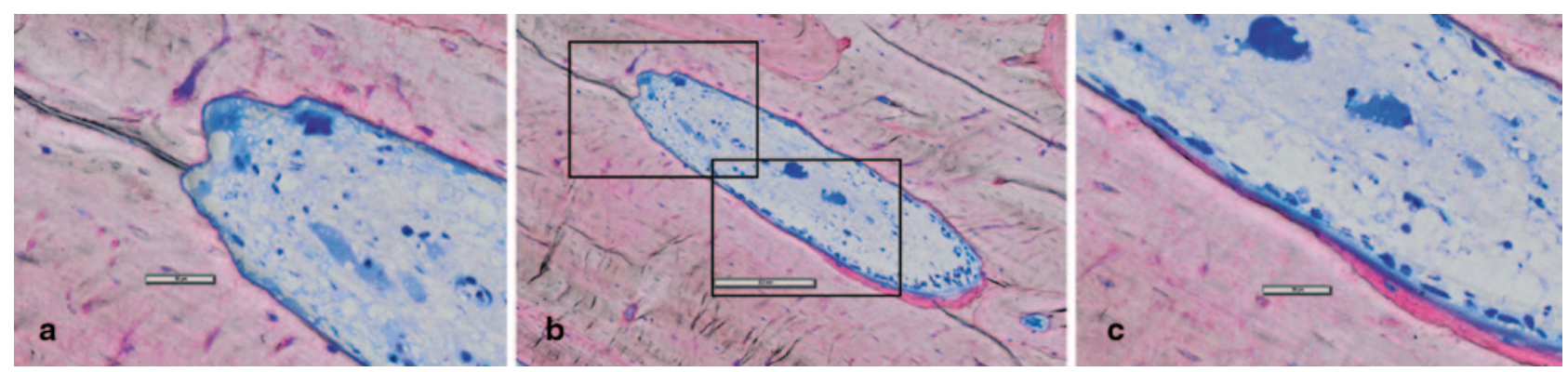

Fig. 1 The "Basic multicellular unit." Bone-resorbing osteoclasts remove the bone and prepare the site for the following bone-forming osteoblasts. The blood capillaries are a sign that osteoclast and osteoblasts develop out of their respective hematopoietic and mesenchymal progenitors. Thus, the $\mathrm{BMU}$ holds the microenvironment that initiates osteoclastogenesis and the osteoblastogenesis, and as the two processes are functionally coupled, also the underlying molecular mechanisms are beginning to be discovered. Among the key regulators of this process are the osteocytes that can RANKL and sclerostin, thereby pushing osteoclastogenesis while supressing osteoblastogenesis, respectively. Also, osteoclasto-

multicellular unit" (BMU) in the cortical bone (Fig. 1) or the "Howship's lacunae" in the trabecular compartment. In both anatomical locations, the bone-resorbing osteoclast and the bone-forming osteoblasts coordinately work on the remodeling of bone, as proposed early on by Frost [1], refined by Parfitt [2], and recently updated by Sims and Martin [3] and Delaisse [4]. Modeling is the structural adaptation of bone during growth and to functional loading where osteoblast and osteoclast work independently [1]. Remodeling and modeling depend on the recruitment of the respective progenitors, which are hematopoietic cells for osteoclasts and mesenchymal cells for osteoblasts. Considering further that cells have a limited life span and require constantly renewal, understanding bone remodeling is challenging -in physiologic situation, but, even more, in pathologic conditions such as osteoporosis [5].

Bone resorption is accomplished by osteoclasts, highly specialized multinucleated cells in intimate contact with the bone matrix. Mature osteoclasts have two characteristic morphological features: the sealing zone and the ruffled border. The sealing zone attaches the osteoclast via $\alpha_{\mathrm{v}} \beta_{3}$ integrins to the extracellular bone matrix, particularly to osteopontin and bone sialoprotein [6]. The intracellular domains of the integrins are connected to podosomes, which are F-actin cores associated with other structural proteins (vinculin, paxillin, and talking) and kinases (small GTPases, c-Src, and Pyk2) [7]. The sealing zone tightens the osteoclasts toward the resorptive compartment, allowing the cell to generate a secondary lysosome with low $\mathrm{pH}$ and proteases. The ruffled border is formed by the fusion of intracellular vesicles containing the enzymes and transmembrane proteins driving bone resorption.

The vacuolar $\mathrm{H}^{+}$-ATPase (V-ATPase) and the chloride channel type 7, pump hydrochloride acid into the resorp- kines and growth factors released by the osteoclasts likely control osteoblastogenesis. Moreover, the osteoclasts leave an osteoblastophilic surface. The birth and death of bone cells and the complex interplay between the two key effector cells hold the key to understand the biology and also the pathophysiology of bone remodeling and reveal potential clinical targets, for example, cathepsin $\mathrm{K}$ to which this review series is dedicated. a Osteoclasts at the resorption front; b overview on a active osteon; c osteoblast at the formation front. Note the blood vessels in the center on the osteon. The histology was taken from the porcine mandible.

tion lacunae. The carbonic anhydrase type II provides the protons. SLC4A2 exchanges $\mathrm{Cl}^{-}$for $\mathrm{HCO}_{3}{ }^{-}$at the basolateral site. Together, these enzymes drive the acidification of the resorption lacunae and thus the lysis of the mineralized matrix [8]. The remaining collagen-rich matrix is removed by proteases, mainly cathepsin $\mathrm{K}$ [9]. Calcium, phosphate, matrix degradation products, and also growth factors stored in the bone matrix are transported through the osteoclast and released on the basolateral site, where blood vessels provide the connection to the circulation. Thus, urine and serum are used to monitor collagen degradation products [10] (Fig. 2).

\section{Pioneer work on osteoclastogenesis}

More than 3 decades ago, it became evident that osteoclasts are of hematopoietic origin [11, 12]. Multinucleated osteoclast-like cells expressing tartrate-resistant acid phosphatase and capable of resorbing dentine were originally generated from murine bone marrow [13]. This process was induced by the same hormones and cytokines that are responsible for bone resorption in vivo: $1,25(\mathrm{OH}) 2$ vitamin D3, prostaglandin E2, PTH, and inflammatory cytokines of the IL- 6 family [14]. The presence of mesenchymal cells was found to be essential allowing the hormones and cytokines to induce osteoclastogenesis [15]. It was therefore proposed that mesenchymal cells produce a membrane-bound factor termed "stromal osteoclast-forming activity" (SOFA) or "osteoclast differentiation factor" (ODF) [11, 14]. In 1997, this osteoclastogenic factor, now termed RANKL, was discovered by Snow Brand [16-18] and Amgen [19, 20], but was first described to link T cells and dendritic cells [21, 22].

RANKL competes with its decoy receptor OPG for activating RANK on osteoclasts and the respective progeni- 


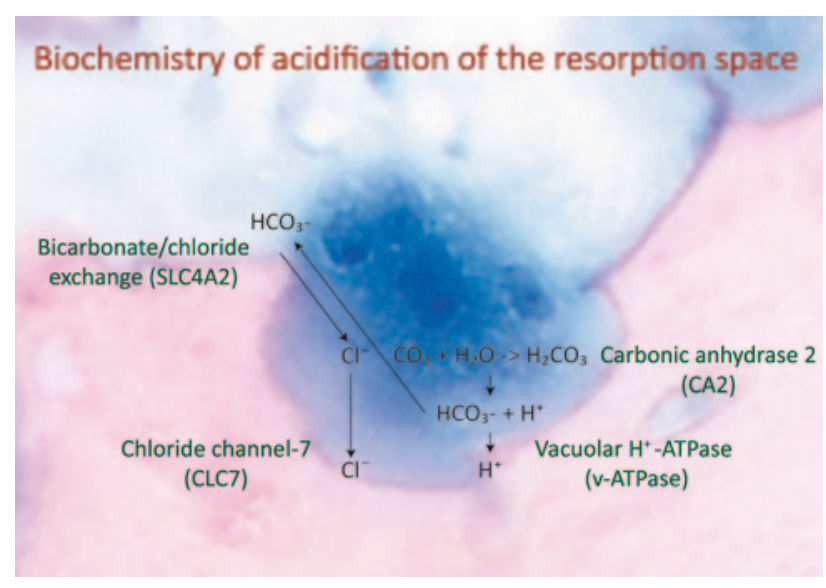

Fig. 2 The biochemistry of acidification of the resorption lacunae. Once the osteoclasts have sealed off the space between their apical cell membrane and the underneath bone matrix, protons and proteolytic enzymes are pumped into this secluded space, which later becomes the "cutting cone" (BMU) or the Howship's lacuna. The sealing zone is rich in ${ }_{v} \alpha_{3}$ integrins that connect to SIBLINGs (for Small Integrin-Binding Ligand, $\mathrm{N}$-linked Glycoproteins; e.g., osteopontin and bone sialoprotein) on the bone matrix to the podosomes in the cytoplasm. Acidification is accomplished by the interplay of enzymes: the carbonic anhydrase 2 (CA2) providing the unstable carbonic acid that has equilibrium with protons and bicarbonate. The proton is pumped into the resorption site by the vacuolar $\mathrm{H}^{+}$-ATPase, and the bicarbonate is exchanged for chloride by the respective transporter (SLC4A2). The chloride is also pumped into the resorption site by means of the chloride channel 7 (CLC7). The $\mathrm{pH}$ in the resorption sites drops to approximately $3-4$, which releases minerals from the matrix and is optimal for the proteolytic activity of cathepsin $\mathrm{K}$

tors $[19,20]$. With the recognition that RANKL produced by T-cell that induce osteoclastogenesis, the term "osteoimmunology" was coined [23]. RANKL, by far, exceeds aspects of bone biology [24]. Nevertheless, pharmacologic strategies were developed, first with recombinant OPG [25] and then with a RANKL-neutralizing antibody [26]. Denosumab is now approved in osteoporosis therapy [27] and applied in bone metastasis [28]. Thus, it took 1 decade from discovering the molecular triad to the approval of a global pharmacological product.

\section{Signaling mechanisms controlling osteoclast differentiation, activation, and survival}

RANK is a receptor with an intracellular domain linked to TRAF6, which is characteristic for members of the TNFreceptor family. Downstream are c-fos [29] and NFKB [30], which support the expression of nuclear factor of activated T cell cytoplasmic 1 (NFATc1) [31, 32], together all key transcription factors regulate osteoclastogenesis. However, NFATcl is not exclusively controlled by RANK.

Signaling via immunoreceptor tyrosine-based activation motif (ITAM), as part of Fc receptor common gamma chain (FcR $\gamma$ ) and DNAX-activating protein, $12 \mathrm{kDa}$

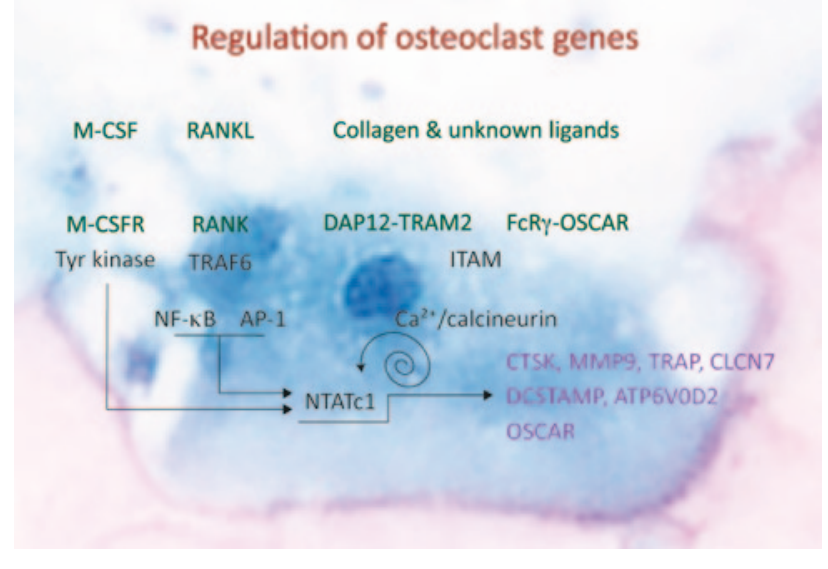

Fig. 3 The regulation of osteoclastic genes. Three main soils of osteoclast signaling are required for osteoclastogenesis, activity, and survival of the cells. In a simplified model, M-CSF activates the receptor tyrosine kinase, RANK signals via TRAF6 and activates NFKB and AP-1 transcription factors and the ITAM-motive containing receptors DAP12, and FcR $\gamma$ stimulate $\mathrm{Ca}^{2+}$-dependent calcineurin signaling-all together cumulate in the increased expression of NFATc1 that is further pushed by feed-forward regulation. Thus, NFATc1 accumulates and, together with other transcription factors, stimulates the expression of the characteristic osteoclast genes responsible for bone resorption, fusion into multinucleated cells, and activation by ligands. Not shown is the signaling involved in formation of the cytoskeleton

(DAP12), is also essential for osteoclastogenesis [33]. The respective costimulatory receptors are osteoclast-associated receptor (OSCAR), triggering receptor expressed in myeloid cells-2 (TREM-2), signal-regulatory protein $\beta 1$ (SIRP $\beta 1)$, and paired immunoglobulin-like receptor-A (PIR-A). For example, OSCAR serves as a collagen receptor that stimulates osteoclastogenesis [34].

ITAM- and also RANKL-dependent signaling activates phospholipase $\mathrm{C} \gamma$ and thus $\mathrm{Ca}^{2+}$ release from the endoplasmic reticulum. Oscillating $\mathrm{Ca}^{2+}$ allows calcineurinsensitive NFATcl autoamplification. Finally, NFATc1 together with other transcription factors (AP-1, PU.1, MITF, etc.) controls the expression of the typical osteoclast genes, e.g., cathepsin K, TRAP, calcitonin receptor, OSCAR, and also genes that regulate cell fusion, i.e., dendritic cell-specific transmembrane protein (DC-STAMP) and the ATPase, $\mathrm{H}^{+}$transporting, lysosomal $38 \mathrm{kDa}, \mathrm{V0}$ subunit d2 (Atp6v0d2) [35-38].

The third key player in osteoclast signaling is the M-CSF receptor (M-CSFR; c-fms). M-CSFR signaling promotes RANK expression, thereby making the progenitor cells more sensitive to RANKL. M-CSFR together with $\alpha_{v} \beta_{3}$ integrin also affect the cytoskeleton by changing c-src, Sky, as well as Rho small GTPases, Vav3, Rac1/2, and Arp2/3 signaling [7, 39]. Together, M-CSFR, RANK, and ITAM signaling control the proliferation, differentiation, fusion, activity, and survival of osteoclasts. All these synchronized steps occur in the unique environment of the BMU (Fig. 3). 


\section{The control of bone remodeling}

Osteoclast are not stand-alone cells in bone remodeling; they team up with the bone-forming osteoblasts and the "amazing" osteocytes [40], which are former osteoblast that are buried in their own matrix, provide the signals to control osteoclastogenesis during bone remodeling, and also control aspects of modeling [41, 42]. Targeted depletion of RANKL in osteocytes but not in osteoblasts results in an osteopetrotic phenotype, causing a paradigm shift in the functional understanding of bone remodeling. Bone resorption is also linked with osteocyte apoptosis [43], which provided new hypothesis about the pathophysiology of osteoporosis induced by loss of steroid hormones, glucocorticoids, or unloading [44]. The osteocytes can also release minerals from their lacunae walls [45], which is particularly impressive during lactation, but act presumably independent of the BMU.

The concept of formation-resorption coupling also advanced, for example, by studies with the sphinosin1-phosophate (S1P) released by osteoclasts [46] and the EphB4.ephrin-B2 signaling complex [47], complement component 3a [48], and semaphorins [49]. Besides these "osteoclastokines," molecules released from the bone matrix, for example, TGF- $\beta$ [50], can target mesenchymal cells. Accumulating evidence supports the central role of the cellular envelope to cover the space where all three phases of bone remodeling-resorption, reversal, and formation-take place [4]. This concept was described in 2001 [51] and has since then been advanced to explain the reversal phase of bone remodeling $[4,52]$. Research on the BMU has a renaissance, providing new hypothesis on the functional coupling on bone resorption and bone formation in health and disease.

This model allows the formulation of a hypothesis why blocking cathepsin $\mathrm{K}$ reduces osteoclast function while bone formation can even be increased [53, 54], and why bisphosphonates, even though the osteoclasts are visible, does not [55]. That almost no osteoclasts are visible with denosumab is not surprising, as their formation is blocked [56]. Bisphosphonates have a negative impact on the canopy coverage; in contrast, the pharmacological inhibition of cathepsin K (odanacatib) increases the extent of the osteoclast-canopy interface [57]. The key to the future bone-anabolic therapies evidently lies in preservation of the canopy coverage of the bone-remodeling compartments, which is basically the BMU.

\section{The past and present of "molecular and cellular basis of bone resorption"}

Osteoclast research has an exciting history and a challenging future that extended the borders of bone research. The authors would like to refer the readers to superb review series published at the millennium change in Nature $[58,59]$ and Science $[60,61]$, and [62] the recent comprehensive works [63], one of which is entitled "The Great Beauty of the osteoclast" [8]. Primers for osteoimmunology [64] along with clinical aspects beyond osteoporosis, e.g., rheumatoid arthritis [65, 66], also needs to be mentioned. Readers should also refer "Bonekey Rep" for comprehensive updates on recent aspects of bone research. The molecular and cellular basis of bone resorption should always be understood in the context of the BMU.

\section{Conflict of interest}

The author declares that there are no actual or potential conflicts of interest in relation to this article.

\section{References}

1. Frost HM. A 2003 update of bone physiology and Wolff's Law for clinicians. Angle Orthod. 2004;74:3-15.

2. Parfitt AM. Osteonal and hemi-osteonal remodeling: the spatial and temporal framework for signal traffic in adult human bone. J Cell Biochem. 1994;55:273-86.

3. Sims NA, Martin TJ. Coupling the activities of bone formation and resorption: a multitude of signals within the basic multicellular unit. Bonekey Rep. 2014;3:481.

4. Delaisse JM. The reversal phase of the bone-remodeling cycle: cellular prerequisites for coupling resorption and formation. Bonekey Rep. 2014;3:561.

5. Manolagas SC. Birth and death of bone cells: basic regulatory mechanisms and implications for the pathogenesis and treatment of osteoporosis. Endocr Rev. 2000;21:115-37.

6. Teitelbaum SL. Osteoclasts and integrins. Ann N Y Acad Sci. 2006;1068:95-9.

7. Novack DV, Faccio R. Osteoclast motility: putting the brakes on bone resorption. Ageing Res Rev. 2011;10:54-61.

8. Cappariello A, Maurizi A, Veeriah V, Teti A. The Great Beauty of the osteoclast. Arch Biochem Biophys. 2014;558C:70-8.

9. Novinec M, Lenarcic B. Cathepsin K: a unique collagenolytic cysteine peptidase. Biol Chem. 2013;394:1163-79.

10. Hlaing TT, Compston JE. Biochemical markers of bone turnover-uses and limitations. Ann Clin Biochem. 2014;51:189-202.

11. Chambers TJ. Regulation of osteoclast development and function. In: Rifkin BR, Gay CV, editors. Biology and physiology of the osteoclast. Boca Raton: CRC Press; 1992. S. 105-28.

12. Marks SC, Jr. The origin of osteoclasts: evidence, clinical implications and investigative challenges of an extra-skeletal source. J Oral Pathol. 1983;12:226-56.

13. Takahashi N, Yamana H, Yoshiki S, Roodman GD, Mundy GR, Jones SJ, Boyde A, Suda T. Osteoclast-like cell formation and its regulation by osteotropic hormones in mouse bone marrow cultures. Endocrinology. 1988;122:1373-82.

14. Suda T, Takahashi N, Martin TJ. Modulation of osteoclast differentiation. Endocr Rev. 1992;13:66-80.

15. Jimi E, Nakamura I, Amano H, Taguchi Y, Tsurukai T, Tamura M, Takahashi N, Suda T. Osteoclast function is activated by osteoblastic cells through a mechanism involving cell-to-cell contact. Endocrinology. 1996;137:2187-90.

16. Tsuda E, Goto M, Mochizuki S, Yano K, Kobayashi F, Morinaga $T$, Higashio $K$. Isolation of a novel cytokine from human fibroblasts that specifically inhibits osteoclastogenesis. Biochem Biophys Res Commun. 1997;234:137-42. 
17. Yasuda H, Shima N, Nakagawa N, Mochizuki SI, Yano K, Fujise N, Sato Y, Goto M, Yamaguchi K, Kuriyama M, Kanno T, Murakami A, Tsuda E, Morinaga T, Higashio K. Identity of osteoclastogenesis inhibitory factor (OCIF) and osteoprotegerin (OPG): a mechanism by which OPG/ OCIF inhibits osteoclastogenesis in vitro. Endocrinology. 1998;139:1329-37.

18. Yasuda H, Shima N, Nakagawa N, Yamaguchi K, Kinosaki M, Mochizuki S, Tomoyasu A, Yano K, Goto M, Murakami A, Tsuda E, Morinaga T, Higashio K, Udagawa N, Takahashi $\mathrm{N}$, Suda T. Osteoclast differentiation factor is a ligand for osteoprotegerin/osteoclastogenesis-inhibitory factor and is identical to TRANCE/RANKL. Proc Natl Acad Sci U S A. 1998;95:3597-602.

19. Simonet WS, Lacey DL, Dunstan CR, Kelley M, Chang MS, Luthy R, Nguyen HQ, Wooden S, Bennett L, Boone T, Shimamoto G, DeRose M, Elliott R, Colombero A, Tan HL, Trail G, Sullivan J, Davy E, Bucay N, Renshaw-Gegg L, Hughes TM, Hill D, Pattison W, Campbell P, Sander S, Van G, Tarpley J, Derby P, Lee R, Boyle WJ. Osteoprotegerin: a novel secreted protein involved in the regulation of bone density. Cell. 1997;89:309-19.

20. Lacey DL, Timms E, Tan HL, Kelley MJ, Dunstan CR, Burgess T, Elliott R, Colombero A, Elliott G, Scully S, Hsu H, Sullivan J, Hawkins N, Davy E, Capparelli C, Eli A, Qian YX, Kaufman S, Sarosi I, Shalhoub V, Senaldi G, Guo J, Delaney J, Boyle WJ. Osteoprotegerin ligand is a cytokine that regulates osteoclast differentiation and activation. Cell. 1998;93:165-76.

21. Wong BR, Josien R, Lee SY, Sauter B, Li HL, Steinman RM, Choi Y. TRANCE (tumor necrosis factor [TNF]-related activation-induced cytokine), a new TNF family member predominantly expressed in T cells, is a dendritic cell-specific survival factor. J Exp Med. 1997;186:2075-80.

22. Anderson DM, Maraskovsky E, Billingsley WL, Dougall WC, Tometsko ME, Roux ER, Teepe MC, DuBose RF, Cosman D, Galibert L. A homologue of the TNF receptor and its ligand enhance T-cell growth and dendritic-cell function. Nature. 1997;390:175-9.

23. Nakashima T, Takayanagi H. Osteoimmunology: crosstalk between the immune and bone systems. J Clin Immunol. 2009;29:555-67.

24. Theill LE, Boyle WJ, Penninger JM. RANK-L and RANK: $\mathrm{T}$ cells, bone loss, and mammalian evolution. Annu Rev Immunol. 2002;20:795-823.

25. Bekker PJ, Holloway D, Nakanishi A, Arrighi M, Leese PT, Dunstan CR. The effect of a single dose of osteoprotegerin in postmenopausal women. J Bone Miner Res. 2001;16:348-60.

26. Bekker PJ, Holloway DL, Rasmussen AS, Murphy R, Martin SW, Leese PT, Holmes GB, Dunstan CR, DePaoli AM. A single-dose placebo-controlled study of AMG 162, a fully human monoclonal antibody to RANKL, in postmenopausal women. J Bone Miner Res. 2004;19:1059-66.

27. Cummings SR, San Martin J, McClung MR, Siris ES, Eastell R, Reid IR, Delmas P, Zoog HB, Austin M, Wang A, Kutilek S, Adami S, Zanchetta J, Libanati C, Siddhanti S, Christiansen C. Denosumab for prevention of fractures in postmenopausal women with osteoporosis. N Engl J Med. 2009;361:756-65.

28. Sun L, Yu S. Efficacy and safety of denosumab versus zoledronic acid in patients with bone metastases: a systematic review and meta-analysis. Am J Clin Oncol. 2013;36:399-403.

29. Grigoriadis AE, Wang ZQ, Cecchini MG, Hofstetter W, Felix $\mathrm{R}$, Fleisch HA, Wagner EF. c-Fos: a key regulator of osteoclast-macrophage lineage determination and bone remodeling. Science. 1994;266:443-8.
30. Iotsova V, Caamano J, Loy J, Yang Y, Lewin A, Bravo R. Osteopetrosis in mice lacking NF-kappaBl and NF-kappaB2. Nat Med. 1997;3:1285-9.

31. Ishida $\mathrm{N}$, Hayashi $\mathrm{K}$, Hoshijima $\mathrm{M}$, Ogawa $\mathrm{T}$, Koga $\mathrm{S}$, Miyatake Y, Kumegawa M, Kimura T, Takeya T. Large scale gene expression analysis of osteoclastogenesis in vitro and elucidation of NFAT2 as a key regulator. J Biol Chem. 2002;277:41147-56.

32. Takayanagi H, Kim S, Koga T, Nishina H, Isshiki M, Yoshida $\mathrm{H}$, Saiura A, Isobe M, Yokochi T, Inoue J, Wagner EF, Mak TW, Kodama T, Taniguchi T. Induction and activation of the transcription factor NFATc1 (NFAT2) integrate RANKL signaling in terminal differentiation of osteoclasts. Dev Cell. 2002;3:889-901.

33. Koga $T$, Inui $M$, Inoue $K$, Kim $S$, Suematsu $A$, Kobayashi E, Iwata T, Ohnishi H, Matozaki T, Kodama T, Taniguchi T, Takayanagi H, Takai T. Costimulatory signals mediated by the ITAM motif cooperate with RANKL for bone homeostasis. Nature. 2004;428:758-63.

34. Barrow AD, Raynal N, Andersen TL, Slatter DA, Bihan D, Pugh N, Cella M, Kim T, Rho J, Negishi-Koga T, Delaisse JM, Takayanagi H, Lorenzo J, Colonna M, Farndale RW, Choi $\mathrm{Y}$, Trowsdale J. OSCAR is a collagen receptor that costimulates osteoclastogenesis in DAP12-deficient humans and mice. J Clin Invest. 2011;121:3505-16.

35. Kim K, Lee SH, Ha Kim J, Choi Y, Kim N. NFATc1 induces osteoclast fusion via up-regulation of Atp6v0d2 and the dendritic cell-specific transmembrane protein (DCSTAMP). Mol Endocrinol. 2008;22:176-85.

36. Yagi M, Ninomiya K, Fujita N, Suzuki T, Iwasaki R, Morita K, Hosogane N, Matsuo K, Toyama Y, Suda T, Miyamoto T. Induction of DC-STAMP by alternative activation and downstream signaling mechanisms. J Bone Miner Res. 2007;22:992-1001.

37. Lee SH, Rho J, Jeong D, Sul JY, Kim T, Kim N, Kang JS, Miyamoto T, Suda T, Lee SK, Pignolo RJ, Koczon-Jaremko B, Lorenzo J, Choi Y. v-ATPase V0 subunit d2-deficient mice exhibit impaired osteoclast fusion and increased bone formation. Nat Med. 2006;12:1403-9.

38. Miyamoto H, Suzuki T, Miyauchi Y, Iwasaki R, Kobayashi T, Sato Y, Miyamoto K, Hoshi H, Hashimoto K, Yoshida S, Hao W, Mori T, Kanagawa H, Katsuyama E, Fujie A, Morioka H, Matsumoto M, Chiba K, Takeya M, Toyama Y, Miyamoto T. Osteoclast stimulatory transmembrane protein and dendritic cell-specific transmembrane protein cooperatively modulate cell-cell fusion to form osteoclasts and foreign body giant cells. J Bone Miner Res. 2012;27:1289-97.

39. Teitelbaum SL. The osteoclast and its unique cytoskeleton. Ann N Y Acad Sci. 2011;1240:14-7.

40. Bonewald LF. The amazing osteocyte. J Bone Miner Res. 2011;26:229-38.

41. Xiong J, Onal M, Jilka RL, Weinstein RS, Manolagas SC, O'Brien CA. Matrix-embedded cells control osteoclast formation. Nat Med. 2011;17:1235-41.

42. Nakashima T, Hayashi M, Fukunaga T, Kurata K, Oh-Hora M, Feng JQ, Bonewald LF, Kodama T, Wutz A, Wagner EF, Penninger JM, Takayanagi H. Evidence for osteocyte regulation of bone homeostasis through RANKL expression. Nat Med. 2011;17:1231-4.

43. Tatsumi S, Ishii K, Amizuka N, Li M, Kobayashi T, Kohno K, Ito M, Takeshita S, Ikeda K. Targeted ablation of osteocytes induces osteoporosis with defective mechanotransduction. Cell Metab. 2007;5:464-75.

44. Manolagas SC, Parfitt AM. For whom the bell tolls: distress signals from long-lived osteocytes and the pathogenesis of metabolic bone diseases. Bone. 2013;54:272-8. 
45. Wysolmerski JJ. Osteocytes remove and replace perilacunar mineral during reproductive cycles. Bone. 2013;54:230-6.

46. Pederson L, Ruan M, Westendorf JJ, Khosla S, Oursler MJ. Regulation of bone formation by osteoclasts involves Wnt/ BMP signaling and the chemokine sphingosine-1-phosphate. Proc Natl Acad Sci U S A. 2008;105:20764-9.

47. Zhao C, Irie N, Takada Y, Shimoda K, Miyamoto T, Nishiwaki T, Suda T, Matsuo K. Bidirectional ephrinB2-EphB4 signaling controls bone homeostasis. Cell Metab. 2006;4:111-21.

48. Matsuoka K, Park KA, Ito M, Ikeda K, Takeshita S. Osteoclast-derived complement component 3a stimulates osteoblast differentiation. J Bone Miner Res. 2014;29:1522-30.

49. Negishi-Koga T, Takayanagi H. Bone cell communication factors and semaphorins. Bonekey Rep. 2012;1:183.

50. Crane JL, Cao X. Bone marrow mesenchymal stem cells and TGF-beta signaling in bone remodeling. J Clin Invest. 2014;124:466-72.

51. Hauge EM, Qvesel D, Eriksen EF, Mosekilde L, Melsen F. Cancellous bone remodeling occurs in specialized compartments lined by cells expressing osteoblastic markers. J Bone Miner Res. 2001;16:1575-82.

52. Andersen TL, Abdelgawad ME, Kristensen HB, Hauge EM, Rolighed L, Bollerslev J, Kjaersgaard-Andersen P, Delaisse JM. Understanding coupling between bone resorption and formation: are reversal cells the missing link? Am J Pathol. 2013;183:235-46.

53. Pennypacker BL, Chen CM, Zheng H, Shih MS, Belfast M, Samadfam R, Duong le T. Inhibition of cathepsin k increases modeling-based bone formation, and improves cortical dimension and strength in adult ovariectomized monkeys. J Bone Miner Res. 2014;29:1847-58.

54. Jensen PR, Andersen TL, Pennypacker BL, Duong le T, Delaisse JM. The bone resorption inhibitors odanacatib and alendronate affect post-osteoclastic events differently in ovariectomized rabbits. Calcif Tissue Int. 2014;94:212-22.

55. Chavassieux PM, Arlot ME, Reda C, Wei L, Yates AJ, Meunier PJ. Histomorphometric assessment of the long-term effects of alendronate on bone quality and remodeling in patients with osteoporosis. J Clin Invest. 1997;100:1475-80.
56. Reid IR, Miller PD, Brown JP, Kendler DL, FahrleitnerPammer A, Valter I, Maasalu K, Bolognese MA, Woodson G, Bone H, Ding B, Wagman RB, San Martin J, Ominsky MS, Dempster DW. Effects of denosumab on bone histomorphometry: the FREEDOM and STAND studies. J Bone Miner Res. 2010;25:2256-65.

57. Jensen PR, Andersen TL, Pennypacker BL, Duong le T, Engelholm LH, Delaisse JM. A supra-cellular model for coupling of bone resorption to formation during remodeling: lessons from two bone resorption inhibitors affecting bone formation differently. Biochem Biophys Res Commun. 2014;443:694-9.

58. Boyle WJ, Simonet WS, Lacey DL. Osteoclast differentiation and activation. Nature. 2003;423:337-42.

59. Teitelbaum SL, Ross FP. Genetic regulation of osteoclast development and function. Nat Rev Genet. 2003;4:638-49.

60. Teitelbaum SL. Bone resorption by osteoclasts. Science. 2000;289:1504-8.

61. Rodan GA, Martin TJ. Therapeutic approaches to bone diseases. Science. 2000;289:1508-14.

62. Edwards JR, Mundy GR. Advances in osteoclast biology: old findings and new insights from mouse models. Nat Rev Rheumatol. 2011;7:235-43.

63. Boyce BF. Advances in the regulation of osteoclasts and osteoclast functions. J Dent Res. 2013;92:860-7.

64. Takayanagi H. New developments in osteoimmunology. Nat Rev Rheumatol. 2012;8:684-9.

65. Redlich K, Smolen JS. Inflammatory bone loss: pathogenesis and therapeutic intervention. Nat Rev Drug Discov. 2012;11:234-50.

66. Schett G, Gravallese E. Bone erosion in rheumatoid arthritis: mechanisms, diagnosis and treatment. Nat Rev Rheumatol. 2012;8:656-64. 